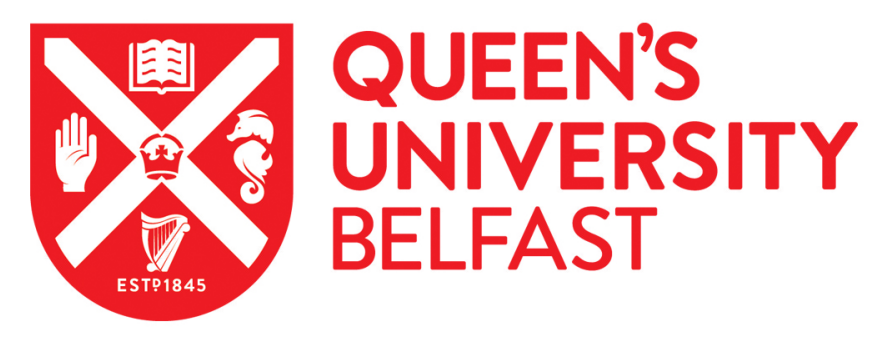

\title{
Spatio-Temporal Analyses of Extracted Citrullus Colocynthis Seeds (Handal Seed Oil) as Biofuel in Internal Combustion Engine
}

Al-Hwaiti, M., Alsbou, E., Haddad, R., Osman Ahmed, A. O., Abu Jrai, A., Al-Muhtaseb, A. H., Hasan, A., Morgan, K., El-Sayed, E-S., Al-Fatesh, A., Fakeeha, A. H., Rooney, D., \& Al-Rawashdeh, H. (2020). SpatioTemporal Analyses of Extracted Citrullus Colocynthis Seeds (Handal Seed Oil) as Biofuel in Internal Combustion Engine. Renewable Energy. https://doi.org/10.1016/j.renene.2020.11.148

Published in:

Renewable Energy

Document Version:

Peer reviewed version

Queen's University Belfast - Research Portal:

Link to publication record in Queen's University Belfast Research Portal

\section{Publisher rights}

Copyright 2020 Elsevier.

This manuscript is distributed under a Creative Commons Attribution-NonCommercial-NoDerivs License

(https://creativecommons.org/licenses/by-nc-nd/4.0/), which permits distribution and reproduction for non-commercial purposes, provided the author and source are cited.

\section{General rights}

Copyright for the publications made accessible via the Queen's University Belfast Research Portal is retained by the author(s) and / or other copyright owners and it is a condition of accessing these publications that users recognise and abide by the legal requirements associated with these rights.

Take down policy

The Research Portal is Queen's institutional repository that provides access to Queen's research output. Every effort has been made to ensure that content in the Research Portal does not infringe any person's rights, or applicable UK laws. If you discover content in the Research Portal that you believe breaches copyright or violates any law, please contact openaccess@qub.ac.uk. 
Spatio-Temporal Analyses of Extracted Citrullus Colocynthis Seeds (Handal Seed Oil) as

\section{Biofuel in Internal Combustion Engine}

3 Mohammad S. Al-Hwaiti ${ }^{1}$, Eid M. Alsbou ${ }^{2}$, Rawan M. Al Haddad ${ }^{3}$, Ahmed I. Osman ${ }^{*}$, Ahmed Abu 4 Jrai ${ }^{1}$, Ala'a H. Al-Muhtaseb ${ }^{5 *}$, Ahmad O. Hasan ${ }^{3}$, Kevin Morgan ${ }^{4}$, El-Sayed M. El-Sayed ${ }^{6}$, Ahmed

$6 \quad{ }^{1}$ Environmental Engineering Department, Faculty of Engineering, Al-Hussein Bin Talal University, P.O.

7 Box20 Ma'an-Jordan.

$8 \quad{ }^{2}$ Chemistry Department, Faculty of Science, Al-Hussein Bin Talal University, P.O. Box20 Ma'an-Jordan.

$9{ }^{3}$ Department of Mechanical Engineering, AL-Hussein Bin Talal University, P.O. Box20 Ma'an-Jordan

${ }^{4}$ School of Chemistry and Chemical Engineering, Queen's University Belfast, Belfast BT9 5AG, Northern Ireland, UK.

${ }^{5}$ Department of Petroleum and Chemical Engineering, College of Engineering, Sultan Qaboos University, Muscat, Oman.

${ }^{6}$ Chemical Refining Laboratory, Refining Department, Egyptian Petroleum Research Institute, Nasr City, Cairo, Egypt.

$10{ }^{7}$ Chemical Engineering Department, College of Engineering, King Saud University, P.O. Box 800, 11 Riyadh 11421, Saudi Arabia. 


\section{Abstract}

16 Herein Handal oil extraction from waste biomass is investigated for biodiesel production via esterification 17 and transesterification processes. Furthermore, the physicochemical characteristics of Handal biodiesel 18 (density, kinematic viscosity, specific gravity, pour point, flash point, and cloud point) was performed along 19 with testing the fuel quality used in internal combustion engines. The flash point of the obtained Handal 20 biodiesel $\left(49.5{ }^{\circ} \mathrm{C}\right)$ was lower than that of petroleum diesel $\left(68.3{ }^{\circ} \mathrm{C}\right)$. While at $40{ }^{\circ} \mathrm{C}$, the kinematic 21 viscosity of used Handal oil (4.476 cSt), which was higher than that of diesel fuel $(2.6 \mathrm{cSt})$ and fossil diesel 22 (2.27 cSt). Pourpoint of the used Handal oil was -9 and lower than that of Handal biodiesel, which is +3. 23 The sulfur content of Handal oils was $193 \mathrm{mg} / \mathrm{kg}$, which was higher than the Handal biodiesel value of 62 $24 \mathrm{mg} / \mathrm{kg}$, but significantly lower than that of diesel fuels $(\leq 100 \mathrm{ppm})$. Similar engine performance regarding 25 thermal efficiency between pure diesel and biodiesel at different engine speeds and loads was detected. The 26 utilisation of such waste stream (Handal wild plant) in the production of biodiesel fuel will aid upcycling 27 an otherwise waste and problematic thermochemical conversion feedstock by adding value for the 28 application in the energy sector.

31 Keywords: Handal seed oil, biodiesel, biofuel, physicochemical properties, Internal Combustion Engine. 


\section{Introduction}

Biofuels are a growing source of energy primarily due to the increase of global demands of fuels combined with environmental impact concerns $[1,2]$. Most of the world production of biodiesel (>95\%) uses edible vegetable-based oils, including coconut, sunflower seed, palm, soybean, peanut, canola, and corn [3]. Thus, a biofuel derived from non-edible resources is an auspicious alternative in several countries, especially developing ones, keeping in mind the fuel versus food debate [4]. Such developing countries are more vulnerable to energy crisis than developed countries, resulting in a high challenge to provide cost-effective energy supply [5, 6]. Vegetable oils have formed renewable feedstock for many industrial uses in various sectors that required "once-through" materials such as lubricants, engine oils, hydraulic fluids and others $[7,8]$. Biodiesel is a carbon-neutral fuel as emissions associated with its combustion are approximately equal to $\mathrm{CO}_{2}$ sequestration of the plants that are the main feedstocks for its production. Conversely, the utilisation of fossil fuels has led to augmented emissions, particularly $\mathrm{CO}_{2}$, resulting in the greenhouse gas effect. The challenge is to decrease dependency on fossil fuel, keeping the environment from $\mathrm{CO}_{2}$ release with carbon sequestration from biomass is one of the negative emission technologies (NETs) that is effective in climate change mitigation [6]. Furthermore, the utilisation of renewable fuel is one of the conventional approaches in climate change strategies.

Vegetable oils obtained from a variety of oils as well as seed crops, featuring high energy density in addition to good fuel characteristics, can be processed to biodiesel with further safe utilisation as a biofuel in engines of compression ignition [9]. The properties obtained from palm oil processing under basic catalyst transesterification method were investigated, and experiments exhibited that the optimum yield value of $88 \%$ was at a reaction temperature of 60 ${ }^{\circ} \mathrm{C}$, reaction time of 40 minutes, and methoxide to oil ratio of $6: 1$ [10]. The produced biodiesel had similar properties to the American Standard for Testing and Material (ASTM)) D 6751, 
and European Norm (EN)14214. Other oils that have been investigated for biodiesel production from various feedstocks, including Croton Megalocarpus [11], Mahua (Madhuca Indica) [12], Thumba (Citrullus colocynth) [13-15].

The transesterification process to produce biodiesel was found to be the most appropriate and adequate route. Alkali-catalysed transesterification process, in particular, is commonly used in producing biodiesel production but requires optimisation for parameters that governed the production process [16]. The transesterification technique is more practical when performed for scaling-up, though it can still be a promising pathway for small scale areas, especially in developing countries. Vegetable oils (heated or blended), when utilised as an alternative to petroleum fuel, they afford highly attractive vegetable oil-diesel blends with encouraging features to be explored by the scientific community [17-19]. Transesterification process is an equilibrium-based reaction which is reversible and relies on various factors such as residence time, reaction temperature, catalyst loading and methanol: oil ratio [20].

Hoekmana et al. [21] reported that several fuel properties such as cetane number, viscosity, iodine value, specific gravity, and low-temperature efficiency are associated with the degree of unsaturation within the fatty acid methyl ester (FAME) structure. Back to the structure of FAME, it is difficult to identify a particular composition that makes it ideal for all the necessary fuel characteristics. Biodiesel should have relatively low concentrations of saturated long-chain FAME as well as poly-unsaturated FAME for a sufficient operating efficiency. Fuel characteristics such as flash point, kinematic viscosity, and calorific value, density were determined for various biodiesel in comparison with diesel. Plant oils possess high viscosity with an inability to be employed as a fuel; thus, the viscosity should be reduced through the chemical process for transesterification. Such a process includes a catalytic reaction between triglyceride and three alcohol molecules, yielding a mix of fatty acids, alkyl ester and glycerol as a significant by-product [22-25]. Patil et al. [24] used triglycerides vegetable oils' 
transesterification to synthesise biodiesel, including catalytic reaction with short-chain alcohols (mostly methanol). Other alcohols such as ethanol, propanol, and butanol are highly miscible in oil, making the next separation step highly challenging and costly. There have been many reports related to the biodiesel blends for engine testing to characterise the fuel performance, including biodiesel generated from biomass-based feedstocks such as sunflower seeds [26, 27], Jatropha [28], melon/watermelon seed oil [29], castor oil [30], rubber seed oil [31] and thumba oil $[32,33]$. However, very few studies were performed on the Citrullus Colocynths (Handal) as a non-edible biomass feedstock [34]. In many cases of utilising biodiesel, the achieved findings possess torque outputs, characteristics, and precise fuel consumption similar to those of diesel fuel, which prove its feasibility as a substitute fuel in diesel engines. However, the low cetane number of biodiesels prevented the use of $100 \%$ replacement of diesel, where the results obtained from biodiesel were compared with the diesel fuel as a reference fuel.

Handal is a non-edible, creeping plant that is a poisonous, desert/wild strongly linked to watermelon, which is regarded as a member of the Cucurbitaceous family [35]. It can survive under hyper-arid desert settings of annual precipitation $(<50 \mathrm{~mm})$ and annual temperature $\left(14.8-27.8^{\circ} \mathrm{C}\right)[36,37]$. The plant with a creeper-shaped can grow in sandy soil, especially in a rainy season with fruit production in winter. Handal oil contains a higher content of seed oil; seeds contain 50 wt.\% of a golden yellow-brown oil (advanced biofuel centre), [38]. Herein we aim to extract the seed oil of the Handal plant and investigate the physical as well as chemical characteristics of Handal seed oil, followed by the production of biodiesel using conventional esterification and transesterification technology. To assess the performance of biodiesel, we also reported the engine testbed data for several blends of the produced biodiesel mixed with diesel. 


\section{Experimental work}

106 A schematic demonstration of the process is displayed in Figure 1. The Handal plant was

107 collected from different places in Jordan, as shown in the supplementary information (Figure

$108 \mathrm{~S} 1)$. One sample of $20 \mathrm{~kg}$ of Handal was collected, and then the seeds were removed and

109 cleaned. After that, seeds were dried for three days at room temperature and then were ground

110 using an electric blender (Home Electric blender 400W (T-608 BL) (Figure S2).

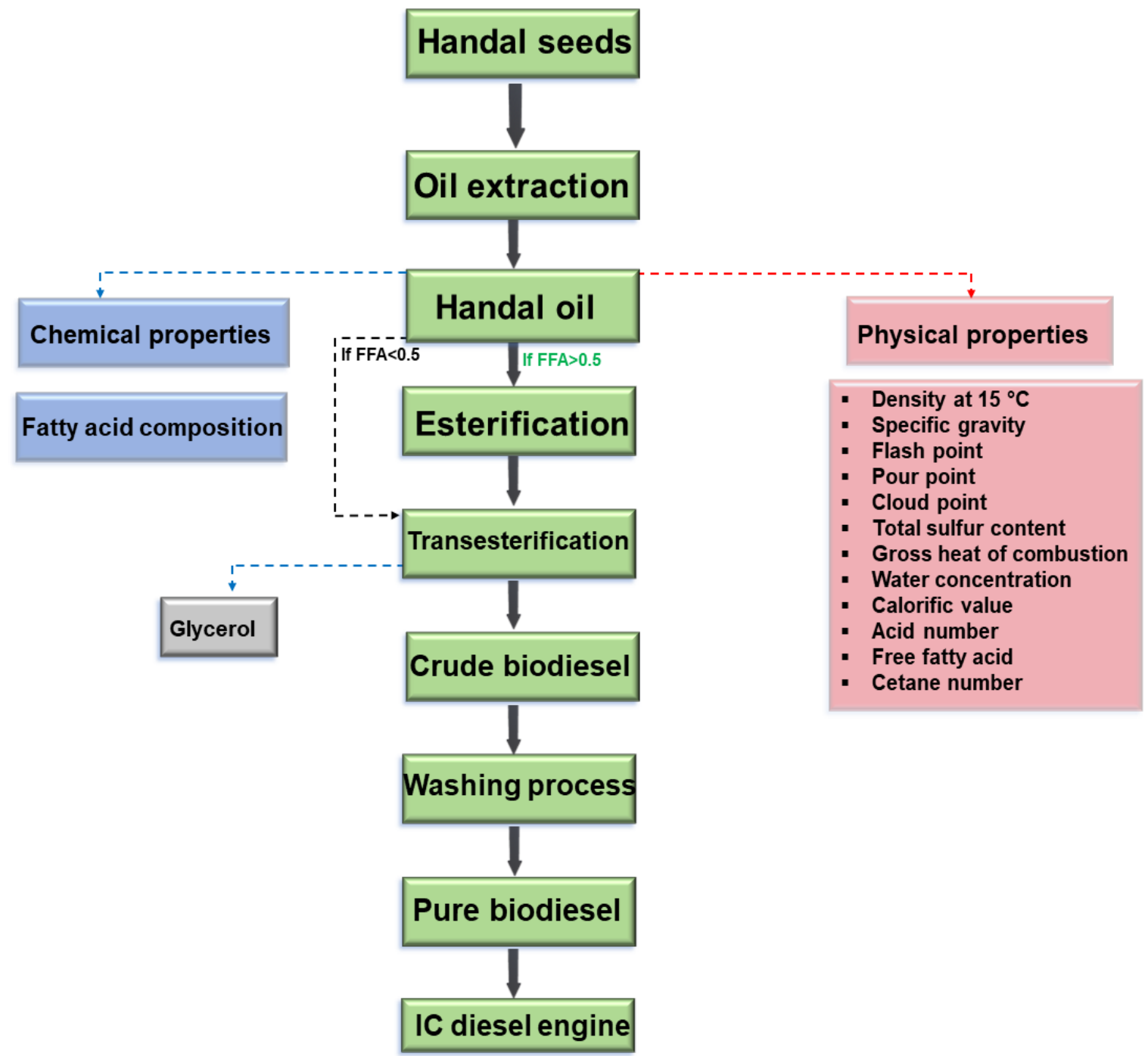

Figure 1: Schematic diagram showing the steps of biodiesel production.

114 For determining the $\mathrm{NaOH}$ amount needed for the transesterification of the oil, $c a .1 \mathrm{~mL}$ oil

115 was dissolved in isopropanol $(10 \mathrm{~mL})$, followed by titration with $0.1 \mathrm{M} \mathrm{NaOH}$ solution 
116 (standardised against KHP). A suitable mass of the catalyst based on this titration is dissolved

117 in methanol (NaOH: Methanol: Oil; $0.0016 \mathrm{~g}: 0.2 \mathrm{~mL}: 1 \mathrm{~mL})$ with 20 min vigorous stirring

118 until dissolution is complete to prepare methoxide $\left(\mathrm{CH}_{3} \mathrm{O}^{-}\right)$. After that, such mixture was

119 brought to the reactor (R-flask) charged with treated moisture-free oil. The obtained mixture

120 was continuously stirred at temperatures range of $60-65^{\circ} \mathrm{C}$ for an hour. The produced mixture

121 was then isolated, with further pouring in a separating funnel for separating glycerol as well as

122 methyl ester of Handal oil. $4 \% \mathrm{H}_{3} \mathrm{PO}_{4}$ solution with steam floatation was used to wash the

123 biodiesel to remove moisture and impurities.

\subsection{Esterification process}

The FFA present in an oil sample was determined as the acid value (AV) by titrating the oil, with the produced mixture is presented in Figure 2.

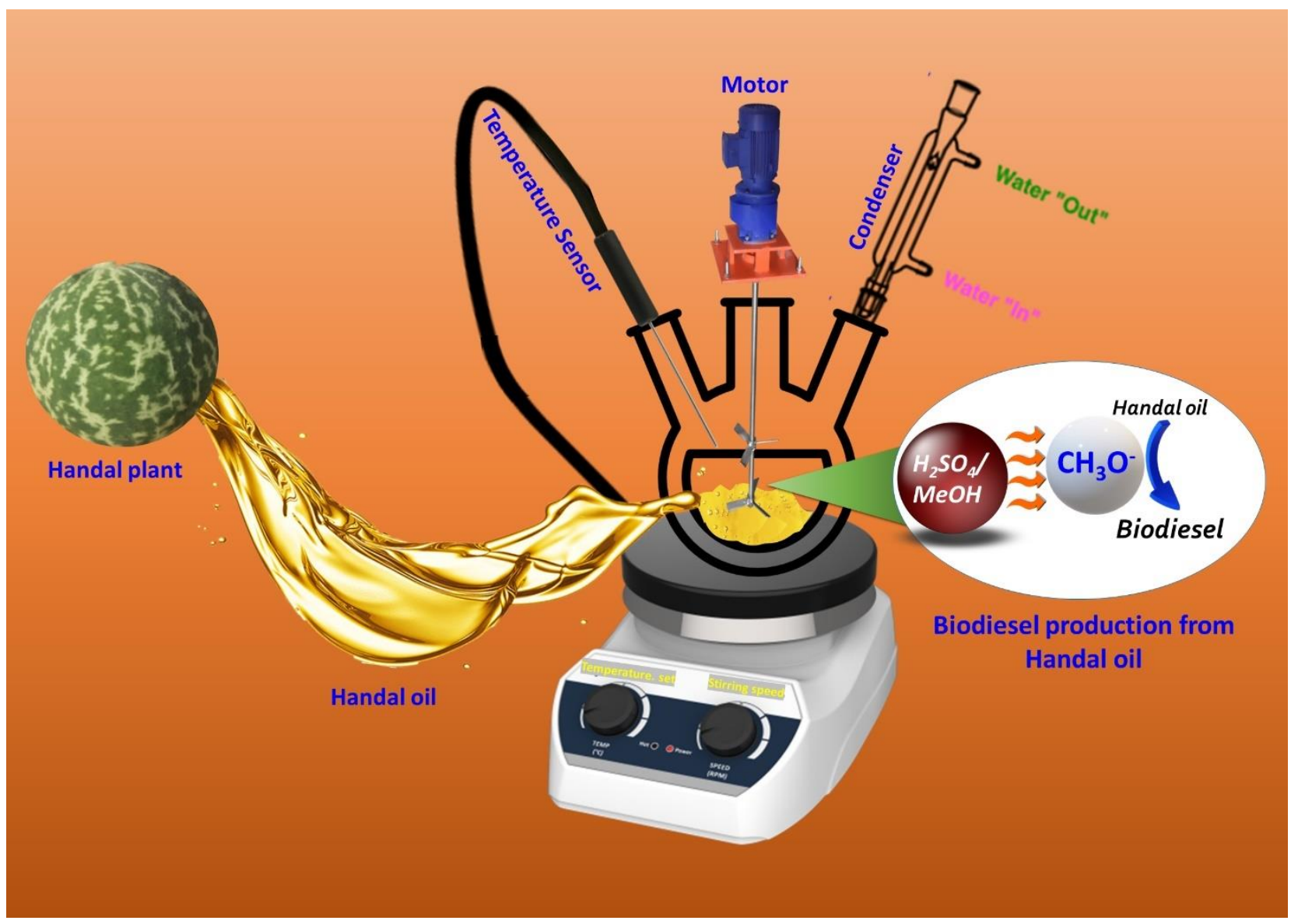


131 The acid value (AV) is expressed as ( $\mathrm{mg} \mathrm{KOH/g}$ oil) according to the equation below [39, 40]:

134 Generally, fatty acid composition percentage is determined by species of plants as well as their

135 growth requirements, so several experiments were done, and the average value of free fatty acid 136 of the Handal oil was $7 \%$, which was a high percentage and needed pretreatment. The

137 esterification prior treatment process is optimised to lower the content of free fatty acid (FFA), 138 and according to Biodiesel Education Program Issue TN \#33, 2018, the esterification based on 139 acid catalysis needs extra use acid as well as methanol, where sulfuric acid is the catalyst and 140 methanol is the reactant. The new free fatty acid was measured to oil to ensure that it was less

$1410.5 \%$. [41]. Esterification is considered as the prevalent utilised process for viscosity reduction 142 of different vegetable oils [42, 43].

\section{$143 \quad 2.2 \quad$ Transesterification process}

144 If the FFA content is less than $0.5 \%$, the oil is ready to be converted into biodiesel. The optimal

145 setup for transesterification of Handal oil with adding methanol amount equivalent to $0.217 \mathrm{x}$

146 [grams of triglycerides unreacted] and sodium methoxide amount equivalent to [0.25 + (\%FFA)

$1470.190] / 100 \times$ [grams of triglycerides unreacted]. The detailed procedures are shown in the 148 supplementary information. This was followed by the washing process, where water was used

149 for purification; thus, the separator funnel was charged with hot distilled water to wash the

150 crude biodiesel. Then the separating funnel was shaken gently to mix water with crude 151 biodiesel. The layers were permitted for settling for one day. The bottom aqueous layer was 
152

153

runoff, while frequent washing process ( 3 to 4 more times) was performed until realising clear water. To remove undesired components such as the excess methanol or residual water, the washed biodiesel samples were dried at $110{ }^{\circ} \mathrm{C}$ for $2 \mathrm{hrs}$.

\subsection{Physical and chemical analyses}

Physical as well as chemical characteristics of oil in addition to biodiesel of the samples were carried out guided by the standard methods. Test methods have been utilized as follows: Density (ASTM D4052-1a), specific gravity (ASTM D4052-1a), kinematic viscosity (ASTM D445-19), flash point (ASTM), pour point (ASTM D97-17b), cloud point (ASTM D2500-17a), copper correction(ASTM D130-19), carbon residue (ASTM D189-06), Gross Heat of Combustion (ASTM D240-17), sulfur content (ASTM D4294-16), water concentration (ASTM D6304-16e1), Ash content (ASTM D482-13), cold filter plugging point (BS EN116:2015).

The samples were subjected to chemical analyses governed by standard test methods: ASTM using Gas Chromatography-Mass Spectrometry analysis (GC-MS) analysis. GC-MS was employed for determining the composition of the biodiesel from Handal seeds oil. Handal oil molecular weight was determined utilising fatty acid composition. The preparation of biodiesel samples intended to measurements of GC-MS was realised through different methods, as stated by [44], as shown in the supplementary. The FAME contents of Handal oil biodiesel were determined by GC-MS (Shimadzu qp2010 Plus, Japan) equipped with a fused-silica capillary column (DB-5MS (30 m x $0.25 \mathrm{~mm}$ I.D x $0.25 \mu \mathrm{m}$ of film thickness) (J \& W Scientific, Folsom, California)).

\subsection{IC engine experiments setup}

The performance testing internal combustion engine was carried out for the produced biodiesel. For performance testing internal combustion engine purposes, four blends consisting of Handal 
175 biodiesel with diesel were prepared by volume as B20 (20\% Handal oil biodiesel and 80\%

176 diesel fuel), B50 (50\% Handal oil biodiesel and 50\% diesel fuel), B100 (100\% Handal oil

177 biodiesel and 00\% diesel fuel), and B00 (00\% biodiesel and 100\% diesel) to analyse the engine

178 performance characteristics.

\section{3. Results and Discussion}

\section{$180 \quad 3.1 \quad$ Physical and chemical results}

181 Blending biomass-based fuel along with diesel has been widely studied in the literature. Balajee

182 et al. [45] utilised Jatropha and Pongamia Pinnata Methyl Ester (PPME) blend with diesel in

183 the variable compression ratio (VCR) CI engine. The performance as well as combustion

184 properties of B10, B20 and B30 blends of Jatropha and Pongamia with diesel for various compression ratios $(13,14,15,16,17.5)$ have been studied, and such blends could replace pure diesel as a substitute fuel source. Sivakumar et al. [46] assessed both efficiency and combustion

187 properties in a given diesel engine using Thumba biodiesel and blends with diesel. On a volume basis, the preparation of blends was realised as of $20,40,60$ and $80 \%$ biodiesel with diesel. The biodiesel characteristics like viscosity, volatility and boiling point are higher than that of diesel fuel. However, again the low cetane number of biodiesels prevented the use of $100 \%$

191 replacement of diesel. An upsurge was accomplished for brake thermal efficiency in all blends 192 when load rises. Thumba oil methyl ester (40\%) and diesel blend (60\%) demonstrated an 193 upsurge in brake thermal efficiency (2\%) in comparison with diesel fuel. The physical 194 characteristics of Handal oil, as well as its biodiesel, are shown in the Tables (1-3). The results 195 discussed below are for different characteristics of the biodiesel derived from used vegetable 196 oils in comparison to those of pure diesel fuel.

197 Handal oil density is $899 \mathrm{~kg} / \mathrm{m}^{3}$, whereas that of biodiesel was $888 \mathrm{~kg} / \mathrm{m}^{3}$ (Tables 1 and 2). It is 198 higher than that of standard diesel ranged between $820-870 \mathrm{~kg} / \mathrm{m}^{3}$ located in Jordan and 
marginally higher (nearly $6 \%$ ) over diesel $\left(835 \mathrm{~kg} / \mathrm{m}^{3}\right)$ Tables $(1$ and 3$)$. At $15^{\circ} \mathrm{C}$, the density 200 of used Handal oil $\left(899 \mathrm{~kg} / \mathrm{m}^{3}\right)$ was higher density than those of diesel fuel $\left(850 \mathrm{~kg} / \mathrm{m}^{3}\right)$ and 201 fossil diesel $\left(880 \mathrm{~kg} / \mathrm{m}^{3}\right)$. At $15^{\circ} \mathrm{C}$, Handal biodiesel density $\left(888 \mathrm{~kg} / \mathrm{m}^{3}\right)$ was relatively higher 202 than those of Jatropha biodiesel $\left(879 \mathrm{~kg} / \mathrm{m}^{3}\right)$ and Babassu biodiesel $\left(879 \mathrm{~kg} / \mathrm{m}^{3}\right)$ in another 203 related research [47]. At the same time, it showed a lower value than that of Karanja biodiesel $204\left(929 \mathrm{~kg} / \mathrm{m}^{3}\right)($ Table 3) [47]. The limit value proposed in pre-standard fuels for vegetable oil compatible combustion engines - fuel derived from rapeseed oil is in the range of 900-960 $\mathrm{kg} / \mathrm{m}^{3}$, so as not to eliminate vegetable oils including jatropha, castor, mahua, babassu and neem oil [48], indicating that density of Handal agrees with pre-standard fuels for vegetable oil 208 compatible combustion engines-fuel. In addition, it is important to regulate the density because 209 a fuel pump is a volumetric unit. Thus, for almost the same higher heating value (HHV), lowdensity fuel means that the energy density for each unit of volume reduces, resulting in a lower 211 ratio of fuel-air equivalence in the inside combustion chamber as well as a reduction in energy 212 produced per cycle. This should impact the brake-specific fuel consumption (BSFC).

213 Table 1: Physical properties of used Handal oil with those of Thumba oil.

\begin{tabular}{|c|c|c|c|c|c|c|c|}
\hline \multirow[t]{2}{*}{ Properties } & \multirow[t]{2}{*}{ Unit } & \multicolumn{2}{|c|}{ Handal } & \multicolumn{2}{|c|}{ Thumba (India)1 } & \multicolumn{2}{|c|}{$\begin{array}{l}\text { Thumba } \\
\text { (India)2 }\end{array}$} \\
\hline & & Oil & Biodiesel & Oil & Biodiesel & Oil & Biodiesel \\
\hline Density at $15^{\circ} \mathrm{C}$ & $\mathrm{Kg} / \mathrm{m}^{3}$ & 899.3 & 888.2 & & & & \\
\hline Specific gravity at $20^{\circ} \mathrm{C}$ & ---- & 0.898 & 0.886 & 0.905 & 0.835 & 0.880 & 0.833 \\
\hline Kinematic viscosity at $40{ }^{\circ} \mathrm{C}$ & $\mathrm{cSt}$ & 16.49 & 4.476 & 31.52 & 2.72 & 5.3 & 2.6 \\
\hline Flash Point & ${ }^{\circ} \mathrm{C}$ & $\begin{array}{l}142- \\
152\end{array}$ & 49.5 & 201 & 66 & 187.5 & 65.5 \\
\hline Pour point & ${ }^{\circ} \mathrm{C}$ & -9 & +3 & -5 & -20 & -8 & -12 \\
\hline Cloud point & ${ }^{\circ} \mathrm{C}$ & +5 & +9 & & & -1 & -5 \\
\hline Copper corrosion $3 \mathrm{hrs}$ at $50{ }^{\circ} \mathrm{C}$ & ---- & 1a & 1a & & & & \\
\hline Total sulfur content & $\mathrm{mg} / \mathrm{Kg}$ & 193 & 62 & & & & \\
\hline Gross heat of combustion & $\mathrm{MJ} / \mathrm{Kg}$ & 39.603 & 39.599 & & & & \\
\hline Water concentration & $\mathrm{mg} / \mathrm{Kg}$ & 592 & 1070 & & & & \\
\hline Conradson carbon residue & wt & - & 0.5 & & & 0.01 & \\
\hline Cold filter plugging point, CFPP & ${ }^{\circ} \mathrm{C}$ & - & 0 & & & & \\
\hline
\end{tabular}




\begin{tabular}{|c|c|c|c|c|c|c|c|}
\hline Calorific Value & $\mathrm{MK} / \mathrm{Kg}$ & 39.603 & 39.599 & & & 39.80 & 46.05 \\
\hline Acid number & $\begin{array}{c}\mathrm{mgKO} \\
\mathrm{H} / \mathrm{g}\end{array}$ & 0.52 & & & & & \\
\hline Free Fatty acid & $\%$ & $>1$ & 0 & $>1$ & 0 & & \\
\hline Cetane Number & - & - & - & 45 & 47 & & \\
\hline
\end{tabular}

216 Table 2: Properties of different vegetable oils [47])

\begin{tabular}{|c|c|c|c|c|c|c|c|c|}
\hline Oils & $\begin{array}{l}\text { Kinematic } \\
\text { Viscosity }\end{array}$ & Density & $\begin{array}{l}\text { Heating } \\
\text { Value }\end{array}$ & $\begin{array}{l}\text { Cloud } \\
\text { Point }\end{array}$ & $\begin{array}{l}\text { Pour } \\
\text { Point }\end{array}$ & $\begin{array}{l}\text { Flash } \\
\text { Point }\end{array}$ & $\begin{array}{l}\text { Cetane } \\
\text { Number }\end{array}$ & $\begin{array}{l}\text { Carbon } \\
\text { Residue }\end{array}$ \\
\hline & $\left(\mathrm{cSt} 40^{\circ} \mathrm{C}\right)$ & (kg/m3) & (MJ/kg) & $\left({ }^{\circ} \mathrm{C}\right)$ & $\left({ }^{\circ} \mathrm{C}\right)$ & $\left({ }^{\circ} \mathrm{C}\right)$ & & $(w / w)$ \\
\hline Handal & 16.49 & 899.1 & 39.60 & +5.0 & -9.0 & 221 & - & - \\
\hline Thumba & 31.52 & 905.0 & 39.80 & -1.0 & - & 201 & 45 & - \\
\hline Jatropha & 49.90 & 921.2 & 39.71 & 16.0 & 8.0 & 240 & $40-45$ & 0.64 \\
\hline Karanja & 46.50 & 929.0 & 38.80 & 13.2 & 6.0 & 248 & 40 & 0.64 \\
\hline Rapeseed & 37.0 & 911.0 & 39.70 & -3.9 & -31.7 & 246 & 37.5 & 0.30 \\
\hline Neem & 57.00 & 938.1 & 39.40 & 8.0 & 2.0 & 295 & 47 & 0.96 \\
\hline Sunflower & 33.90 & 916.2 & 39.61 & 7.2 & -15.0 & 274 & 37.1 & 0.23 \\
\hline Soybean & 32.60 & 914.3 & 39.60 & -3.9 & -12.0 & 254 & 38 & 0.27 \\
\hline Coconut & 27.70 & 915.0 & 37.1 & - & - & 281 & 52 & 0.13 \\
\hline Cotton Seed & 33.51 & 914.1 & 39.4 & 1.7 & -15.0 & 234 & 42 & - \\
\hline Rice Bran & 28.70 & 937.1 & 38.9 & 13.0 & 1.0 & 200 & 30 & 0.24 \\
\hline Peanut & 39.60 & 902.0 & 39.7 & 12.8 & -6.7 & 271 & 42 & - \\
\hline Linseed & 27.20 & 923.0 & 39.3 & 1.7 & -15.0 & 241 & 34.6 & - \\
\hline Palm & 39.61 & 918.1 & 36.5 & 27.0 & -15.0 & 271 & 42 & 0.043 \\
\hline Corn & 34.90 & 909.0 & 39.5 & -1.1 & -40.0 & 277 & 37.6 & 0.24 \\
\hline Babassu & 30.32 & 946.0 & - & 20.0 & - & 150 & 38 & - \\
\hline Tallow & - & - & 40.0 & - & - & 201 & - & 6.10 \\
\hline
\end{tabular}

218 The specific gravity of Handal oil is 0.898 at $20^{\circ} \mathrm{C}$, while in biodiesel was observed for 0.886 .

219 The specific gravity of Thumba oil is slightly variable between 0.880 and 0.905 . However, the 220 specific gravity was reported that 0.835 in Thumba biodiesel (Table 1 ).

221 The significant physical characteristics of Handal oils shown in Table (1) indicate that the

222 kinematic viscosity of Handal oils is $16.49 \mathrm{cSt}$ at $40{ }^{\circ} \mathrm{C}$, which is higher than that of the diesel 223 value by four times. Table (3) shows that Handal oil was lower than that of vegetable oils, 224 ranged between $27-57 \mathrm{cSt}$ at $40{ }^{\circ} \mathrm{C}$ and slightly lies within the range of vegetable biodiesel (3$22515 \mathrm{cSt}$ at $40{ }^{\circ} \mathrm{C}$ ). At $40{ }^{\circ} \mathrm{C}$, the kinematic viscosity of used Handal oil (4.476 cSt), which was 
higher than that of diesel fuel (2.6) and fossil diesel (2.27 cSt), while it was lower than Jatropha

227 biodiesel $(5.65 \mathrm{cSt})$, Karanja biodiesel $(6.87 \mathrm{cSt})$ in addition to Rapeseed seed oil $(7.2 \mathrm{cSt})$. The

vegetable oil used has been noticed to build corrosion based on copper strip.

Table 3: Certain fuel-related characteristics of biodiesel derived from various vegetable oils 230 [47].

\begin{tabular}{|c|c|c|c|c|c|c|c|c|}
\hline Biodiesel & $\begin{array}{l}\text { Kinematic } \\
\text { Viscosity }\end{array}$ & Density & $\begin{array}{l}\text { Heating } \\
\text { Value }\end{array}$ & $\begin{array}{l}\text { Cloud } \\
\text { Point }\end{array}$ & $\begin{array}{l}\text { Pour } \\
\text { Point }\end{array}$ & $\begin{array}{l}\text { Flash } \\
\text { Point }\end{array}$ & $\begin{array}{l}\text { Cetane } \\
\text { Number }\end{array}$ & $\begin{array}{l}\text { Carbon } \\
\text { Residue }\end{array}$ \\
\hline & $\left(\mathrm{cSt} 40^{\circ} \mathrm{C}\right)$ & $\left(\mathrm{kg} / \mathrm{m}^{3}\right)$ & (MJ/kg) & $\left({ }^{\circ} \mathrm{C}\right)$ & $\left({ }^{\circ} \mathrm{C}\right)$ & $\left({ }^{\circ} \mathrm{C}\right)$ & & $(w / w)$ \\
\hline Diesel & 2.75 & 835 & 42.25 & -15 & -20 & 66 & 47 & 0.001 \\
\hline Handal & 4.48 & 888 & - & +9 & +3 & 50 & - & 0.5 \\
\hline Thumba & $3.83-5.86$ & 889 & 39.37 & -5 & - & 66 & 53 & - \\
\hline Jatropha & 5.65 & 879 & 38.5 & 13 & - & 175 & 50 & - \\
\hline Karanja & 6.87 & 897 & 37.9 & - & -1 & 187 & 49 & 0.05 \\
\hline Rapeseed & 7.2 & 883 & 37.37 & - & -12 & - & 51 & - \\
\hline Neem & 15 & 882 & 38.5 & - & - & 180 & 47 & - \\
\hline Sunflower & 4.6 & 868 & 40.58 & 1 & - & 183 & $45-52$ & - \\
\hline Soybean & 4.5 & 872 & 39.76 & 1 & -7 & 178 & $37-45$ & 1.7 \\
\hline Coconut & 3.36 & 866 & 36.1 & - & -4 & 122 & 56 & 0.03 \\
\hline Peanut & 4.9 & 883 & - & 5 & - & 176 & 54 & - \\
\hline Palm & 5.7 & 880 & - & 13 & - & 164 & 62 & - \\
\hline Babassu & 3.6 & 879 & - & 4 & - & 127 & 63 & - \\
\hline Tallow & - & - & - & 12 & 9 & 96 & -- & - \\
\hline
\end{tabular}

232 Viscosity is a good fuel quality indicator prior to application, particularly when the fuel origin

233 is uncertain, or when oil can be polymerised throughout storing [51]. The kinematic viscosity

234 of Handal seed oil is higher than that of conventional diesel fuel and should be preheated to

235 decrease viscosity. It is very important to make sure that pump elements are strong and

236 sufficiently robust for circulating such liquid [48, 52]. Of course, when the fuel has a high

237 viscosity, this affects the efficiency of the pump and make it difficult to rotate and reduce the 238 efficiency of the injection pump. 
Handal oil has a high flashing point almost $\left(>180^{\circ} \mathrm{C}\right)$ and heating value is $39.603 \mathrm{MJ} / \mathrm{kg}$, while 240 that for biodiesel and diesel fuel are 39.5 and $66 \mathrm{MJ} / \mathrm{kg}$, respectively. The flash point of the 241 obtained Handal biodiesel $\left(49.5^{\circ} \mathrm{C}\right)$ was lower than that of petroleum diesel $\left(68.3{ }^{\circ} \mathrm{C}\right)$, diesel 242 fuel $\left(68^{\circ} \mathrm{C}\right)$, and fossil diesel $\left(66^{\circ} \mathrm{C}\right)$. The flash point of biodiesel $\left(49.5^{\circ} \mathrm{C}\right)$ is lower than the 243 values, Thumba biodiesel (66), Jatropha Biodiesel $\left(175^{\circ} \mathrm{C}\right)$, Karanja biodiesel $\left(187^{\circ} \mathrm{C}\right)$, and 244 Neem seed oil $\left(180^{\circ} \mathrm{C}\right)$. The existence of chemically bound oxygen in vegetable oils leads to 245 decreased heating values by around $10 \%$. The fuel flash point is significant safety storage as 246 well as handling specification without an effect on the engine performance [52].

247 The pour point of the Handal oil value is $-9{ }^{\circ} \mathrm{C}$, whereas the biodiesel value is +3 . The results 248 showed that the vegetable oil offered the least values of pour point ranging from $-9{ }^{\circ} \mathrm{C}$ to 40 $249{ }^{\circ} \mathrm{C}$, while Thumba oil holds a pour point of -8 and Thumba biodiesel possess a pour point of 250 12. The corn oil had the pour point of $-40{ }^{\circ} \mathrm{C}$, while the Jatropha oil and Karanja oil have two251 pour point values of 8 and $6{ }^{\circ} \mathrm{C}$, respectively (Table 3). Vegetable oils can be blended in all proportions with petroleum diesel, and such blends can be successfully utilised in engines [53, 54]. It can be concluded that all the chemically modified oil products have the pour points below $2540{ }^{\circ} \mathrm{C}$, which is a desirable property for lubricating oil.

255 The cloud points of Handal oil recorded is at $+5^{\circ} \mathrm{C}$, while biodiesel had the highest cloud point 256 of $+9{ }^{\circ} \mathrm{C}$, indicating an increase in cloud point with increasing carbon content [55]. The used 257 Handal biodiesel held a cloud point $+9^{\circ} \mathrm{C}$, which was over that of diesel fuels $-20^{\circ} \mathrm{C}$. The used 258 Handal oil held a cloud point of $+5^{\circ} \mathrm{C}$, which was over that of Thumba $\left(-1{ }^{\circ} \mathrm{C}\right)$, corn $\left(-1.1^{\circ} \mathrm{C}\right)$, 259 cottonseed $\left(1.7^{\circ} \mathrm{C}\right)$, and rapeseed $\left(-3.9^{\circ} \mathrm{C}\right)$, and lower that of Sunflower $\left(7.2^{\circ} \mathrm{C}\right)$, Karanja $(13$ $\left.260{ }^{\circ} \mathrm{C}\right)$, Jatropha $\left(16^{\circ} \mathrm{C}\right)$, and babassu $\left(-3.9^{\circ} \mathrm{C}\right)$. Table (2) shows the least values of cloud point 261 ranging from $1-4{ }^{\circ} \mathrm{C}$. The cloud point of the Soybean oil used was $-4{ }^{\circ} \mathrm{C}$ and lower than that of 
soybean biodiesel $\left(1^{\circ} \mathrm{C}\right)$. The Thumba oil products oil has the pour points is $-1{ }^{\circ} \mathrm{C}$, while the 263 rice bran oil and peanut oil both have pour point values of $12{ }^{\circ} \mathrm{C}$.

264 The carbon residue of Handal biodiesel $(0.5 \%)$ was more than that of Thumba biodiesel $(0.01 \%)$ 265 and pure diesel possesses $(0 \%)$ as well. The heating value of the utilised vegetable oil biodiesel $266(40 \mathrm{MJ} / \mathrm{Kg})$ is slightly lower than that of diesel fuels (42 MJ/Kg) and petroleum diesel (47 $267 \mathrm{MJ} / \mathrm{Kg})$. The carbon residue of Handal biodiesel (0.5\%) was also higher than that of coconut 268 biodiesel $(0.03 \%)$ but lower than that of soybean biodiesel $(1.7 \%)$. The heating value of vegetable oil (39 MJ/Kg) was slightly higher than that of coconut biodiesel $(36.6 \mathrm{MJ} / \mathrm{Kg})$ from 270 a different study [56, 57].

271 The HHV of Handal biodiesel is relatively high (39.60 MJ/kg) but lower than that of diesel 272 (49.65 MJ/kg) [58]. The HHV values of vegetable biodiesel (36-40 MJ/kg) show slight 273 variation from one type to another but higher than the limit value of diesel (42.2 MJ/kg) (Table 274 1). The biodiesel oxygen content enhances the combustion system and reduces the risk of 275 oxidation. The fuel oxygen content helps to improve the efficiency of combustion with 276 homogenous oxygen distribution in fuel throughout combustion [58]. This leads to the higher 277 efficiency of biodiesel combustion over petro-diesel, while the efficiency of methanol and 278 ethanol combustion is higher than that of diesel as well.

279 The sulfur content of Handal oils $(193 \mathrm{mg} / \mathrm{kg})$ is higher than that of Handal biodiesel (62 $280 \mathrm{mg} / \mathrm{kg}$ ). It has been noticed that sulfur was dramatically decreased upon processing oils and fats 281 to biodiesel (Table 2). Accordingly, sulfur content assessment in vegetable oils to be used in 282 engines is not compulsory. In this regard, sulfur content could reach zero, which is lower than 283 that of diesel fuels $(\leq 100 \mathrm{mg} / \mathrm{kg})[59,60]$. Although light diesel requirements are set at about 

India [59], 5,000 mg/kg in the USA and 10,000 mg/kg in Burkina Faso.

The water content of Handal oil is $0.52 \%$. In comparison, biodiesel had a water content of $0.107 \%$; this shows that most of the water existence comes from biomass, which could be from poor drying or derived from poor oil storage settings by condensation [48]. The moisture which is presented in the used vegetable oil was less than $0.01 \%$, and this ensures hydrolysis of triglycerides by water molecules, forming free fatty acids. The presence of water in vegetable oil deteriorates fuel filter cartridges. Besides, during combustion, in the combustion chambers, water existence in this area will help to cause cavitation problems, especially at the piston head, leading to severe damage in engine head in the future.

The acid content of Handal oil was $0.52 \% \mathrm{mg} \mathrm{KOH} / \mathrm{g}$ oil; however, vegetable oils showed values in the range of $0.01-10 \% \mathrm{wt}$. (corresponding to $0.02-20 \mathrm{mg} \mathrm{KOH} / \mathrm{g}$ oil). The oils acidity is primarily because of free fatty acids (FFA), which comes from the water hydrolysis of triglycerides. It has smaller molecular weights than the triglycerides, which makes acidic vegetable oil easer to flame. Increasing acidity from $0.01 \%$ to $1 \% \mathrm{wt}$, and $10 \% \mathrm{wt}$, led to decreased flash points of $20^{\circ} \mathrm{C}$ and $85{ }^{\circ} \mathrm{C}$, respectively.

Nevertheless, the problem of the fatty acids tends to form corrosion and deposits of carbon and

301 residuals of ash in the engine. Such FFA brought a good quality of vegetable oil when they 302 produced high temperatures through the process and while ageing. These hydrolytic reactions 303 may happen in biomass when they were badly stored (moisture), through pressing under high temperature. The acidity of a given oil is accountable for the destruction of engine consumables 305 (hose, gasket, and so on), corrosion of engine, as well as instability of straight vegetable oil 306 (SVO) through storage. 
307 GC-MS was utilised to determine the biodiesel composition from Hanadal seeds oil. The 308 molecular weight of Handal seed oil was calculated using fatty acid composition and was found 309 to be $885.07 \mathrm{~kg} / \mathrm{mol}$. Four major fatty acids (one saturated and three unsaturated) were detected 310 in Handal oil biodiesel by GC-MS. The composition of FAME in Handal biodiesel was $31190.30 \pm 1.7$ wt. \% of methyl oleate (C18:1) and followed by $4.83 \pm 0.5$ wt. \% of methyl linoleate 312 (C18:2), 2.67 \pm 0.7 wt. \% of methyl linolenate (C18:3), 1.73 \pm 0.4 wt. \% of methyl stearate 313 (C18:0), and 0.6 \pm 0.1 wt. \% of the rest FAMS, as shown in Table 4. This result was different 314 from that obtained for biodiesel produced from Indian Thumba seeds oil, where linoleic acid 315 was highest (56.89 and $61.05 \%)$, followed by oleic acid (18.19 and $17.04 \%$ ), palmitic acid $316(10.70$ and $9.38 \%)$ and stearic acid (7.89 and $7.34 \%)[38,50]$, respectively. The results also 317 demonstrated that the Oleic acid (18:1) is the major fatty acid (90.30\%) in the Handal seed oil, 318 which appears to be an excellent source of oleic acid. The high Oleic acid value is higher than 319 those found in other oils, such as Linseed, Soybean, Corn, Cottonseed, and Palm. The total 320 saturated (Palmitic and Stearic) and unsaturated fatty acid (Oleic and Linoleic) contents of the 321 seed oil were $1.73 \%$ and $95.13 \%$, respectively. According to [62], the presence of major 322 contents from linoleic acid and oleic acid could cause a self-ignition or self-heating of the oils.

323 These two acids (> 95 wt. \% of the oil) with multiple bonds make a Handal oil more likely to 324 have a chemical tendency to self-ignite. 


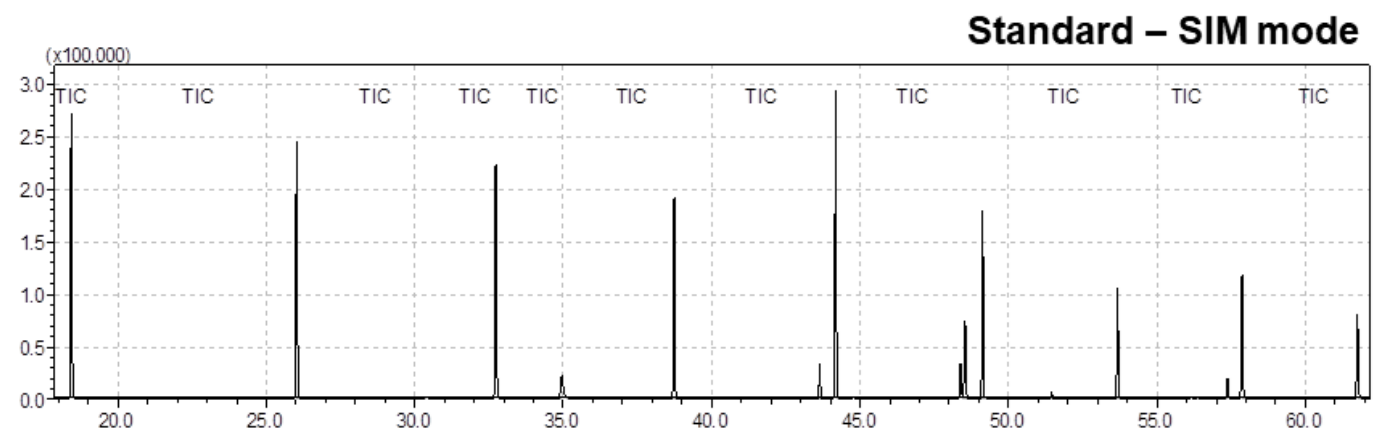

Sample- SIM mode

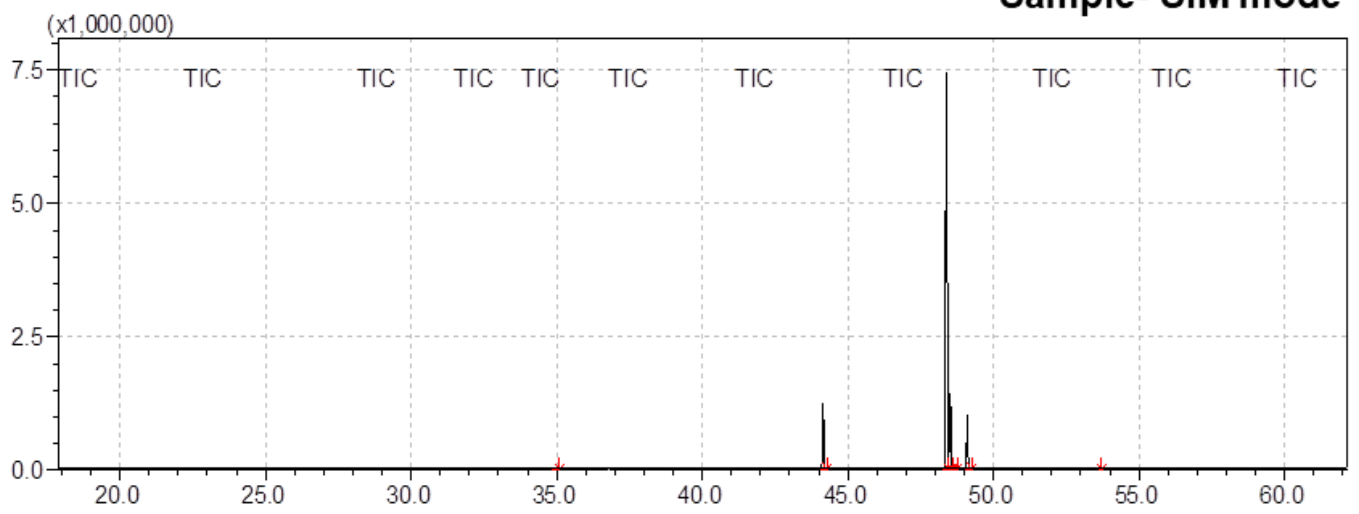

326 Figure 3. GC-MS characterisation of the components of Handal oil and its biodiesel.

327 Table 4: Properties and fatty acid distribution in different common vegetable oil (wt $\%$ ).

\begin{tabular}{|c|c|c|c|c|c|c|}
\hline Vegetable oils & Palmitic & Stearic & Oleic & linoleic & linolenic & Refs \\
\hline & - & (C18:0) & (C18:1) & (C18:2) & (C18:3) & \\
\hline Handal & - & 1.73 & 90.30 & 4.83 & 2.67 & This work \\
\hline Thumba & 10.7 & 7.89 & 18.19 & 56.89 & 61.05 & \multirow{7}{*}{ [63] } \\
\hline Linseed & 5.50 & 3.50 & 19.10 & 15.30 & 56.60 & \\
\hline Soybean & 11.0 & 4.00 & 34.40 & 53.30 & 7.80 & \\
\hline Corn & 10.9 & 2.00 & 25.40 & 59.60 & 1.20 & \\
\hline Cottonseed & 21.6 & 2.60 & 18.60 & 54.40 & 0.70 & \\
\hline Rapeseed & 4.00 & 2.00 & 56.00 & 26.00 & 10.0 & \\
\hline Palm & 42.8 & 4.20 & 40.50 & 10.10 & - & \\
\hline
\end{tabular}




\subsection{Performance and discussion of internal combustion engine biodiesel}

331 The oxygen content of biodiesel improves the combustion process and decreases its oxidation 332 potential. The oxygen content in the fuel structure helps to improve the combustion efficiency 333 and more of homogeneity of oxygen with the fuel during combustion. This leads to higher 334 combustion efficiency of biodiesel than that of petrol-diesel fuel.

335 Torque is the measure of forces that act on an object, leading to object rotation. Torque variation 336 with various Handal blends of biodiesel and pure diesel concerning load is illustrated in Figure 337 (4a). The results detected that the variation of torque for different blends biodiesel and pure diesel (B20, B50, B80, and B00) at an IC engine speed are slightly similar. The values torque created by the engine under various loads for blends of biodiesel and pure diesel showed that

340 the torque was maximum with B20 at $60 \mathrm{~kg}$. In comparison, the maximum torque was $44.44 \mathrm{~N}$ $341 \mathrm{~m}$ at $60 \mathrm{~kg}$ load, which is an indication of better performance. Overall, all different blends 342 biodiesel were exhibited similar results compared with pure diesel, with emphasised on the 343 blended biodiesel (B100).

344 Figure (4b) shows that the blending effect on torque variation is nearly analogous to the pure 345 diesel curve for a wide engine rpm range. Between speed 1000 and $1500 \mathrm{rpm}$, torque remains 346 almost constant with speed; after that, the torque decreases sharply, indicating that further 347 upsurge in speed leads to a reduction in torque. The maximum torque achieved in blend B20 is 34844.44 N.M at $1100 \mathrm{rpm}$ that is slightly higher than pure diesel. Overall, all different blends 349 biodiesel and pure diesel showed relatively similar performance results, exception blend B20 350 showed higher performance than pure diesel, taking into consideration blend B100 shows an 351 acceptable performance compared with pure diesel. This is in agreement with the characteristics in Table 1 and 3 for Handal biodiesel and pure diesel. 

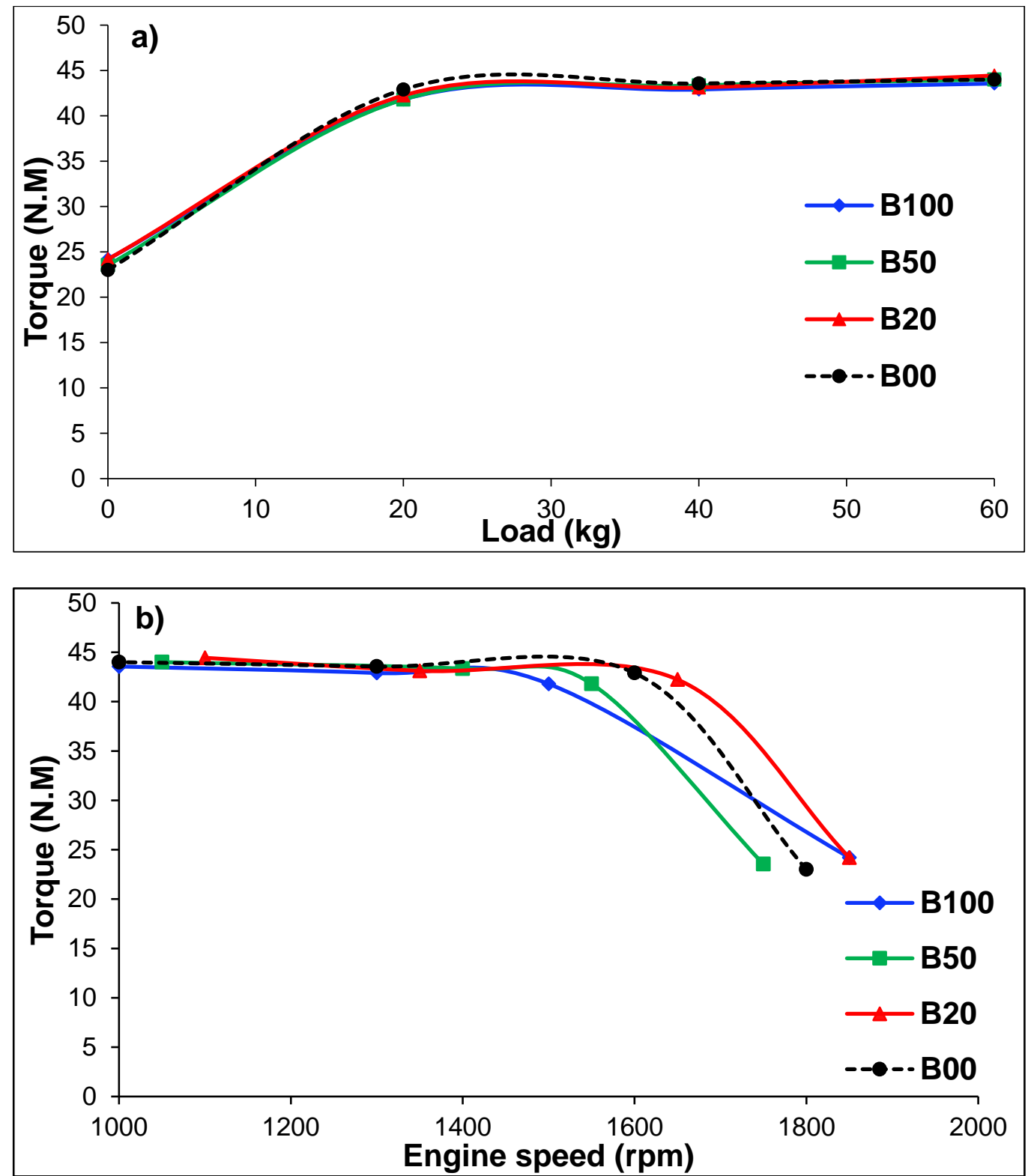

Figure 4: a) torque vs. load for biodiesel blends and b) torque vs. engine speed for biodiesel blends.

358 The brake power (BP) is the produced force by using a motor without considering any of the

359 various auxiliary components that may decrease the real motor speed. The influence of load on

360 BP of a variety of blends of biodiesel and pure diesel is presented in Figure 5a. The result

361 indicated that the blends B20 and B00 were similar values, whereas the different blends B100

362 and B50 were relatively decreased. Also, the result showed that $7.2 \mathrm{~kW}$ is the maximum power 
363 for B20 fuel at $20 \mathrm{~kg}$ load, and it then started a sharp decrease. The brake power at different

364 loads was higher for dual fuel combinations of B20 and B50 than pure diesel.

365 In conclusion, different blends can be suggested to be used in diesel engines with no required

366 changes in the engine. Furthermore, as explained in physical and chemical results in Table 1

367 that showed the sulfur content of Handal oils was $193 \mathrm{mg} / \mathrm{kg}$, which was higher than the Handal

368 biodiesel value of $62 \mathrm{mg} / \mathrm{kg}$, but significantly lower than that of diesel fuels $(\leq 100 \mathrm{ppm})$.

369 Consequently, this should have a positive impact on the emissions when using Handal biodiesel

370 as a substitute for pure diesel fuel. 

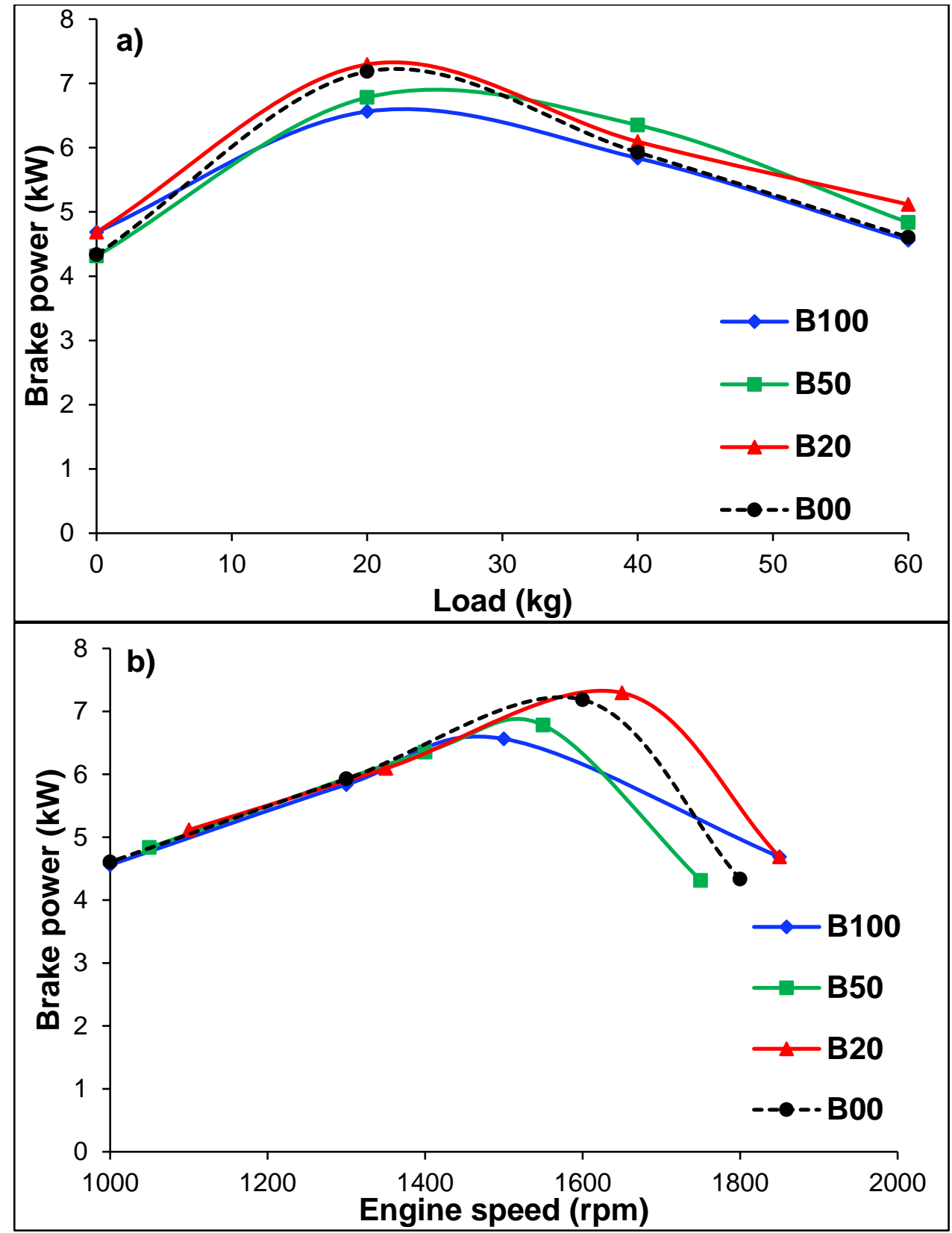

Figure 5: a) brake power (BP) vs. load for biodiesel blends and b) brake power (BP) vs. engine speed for biodiesel blends.

377 The brake power variation versus speed for Handal biodiesel blends when compared to pure 378 diesel is illustrated in (Figure 5b). The results observed that the different blends biodiesel and 379 pure diesel were relatively variable; however, B20 is marginally higher brake power in 380 comparison with pure diesel, which is an indication of better performance. The maximum brake 381 power achieved for B20 is $7.29 \mathrm{KW}$ at $1650 \mathrm{rpm}$. Moreover, all blends result were increased to 382 the maximum, with ranged between $1500 \mathrm{rpm}$ to $1650 \mathrm{rpm}$ and then sharply decreased. 
383 The thermal efficiency results for different blends of biodiesel and pure diesel is illustrated in

384 Figure 6a. The results revealed that the thermal efficiency is relatively the same load for all 385 blends biodiesel and pure diesel. However, with increasing the load, brake thermal efficiency 386 augmented to the maximum $40 \mathrm{~kg}$ of load and $47.2 \%$ thermal efficiency, and then started 387 sharply decreasing for all blends biodiesel and pure diesel. Besides, it was observed that brake 388 thermal efficiency for blend biodiesel B100 was approximately equivalent to that of pure diesel.

389 The brake thermal efficiency variation and engine speed for a variety of blends of biodiesel and 390 pure diesel are demonstrated in Figure $6 \mathrm{~b}$. The result observed that the different blends 391 biodiesel and pure diesel was relatively the same values. It was also observed that when engine 392 speed increased, brake thermal efficiency increases to almost $1500 \mathrm{rpm}$, then started sharply 393 decreasing. The blend B50 shows flocculated values compared with other blends values. In 394 conclusion, the brake thermal efficiency for different blends of biodiesel and pure diesel was 395 relatively the same, focusing on the result of B100 value. Hence, in conclusion, the blend B100 396 can be recommended for use in diesel engines with no need for engine alterations with B20 was 397 better than B00. 


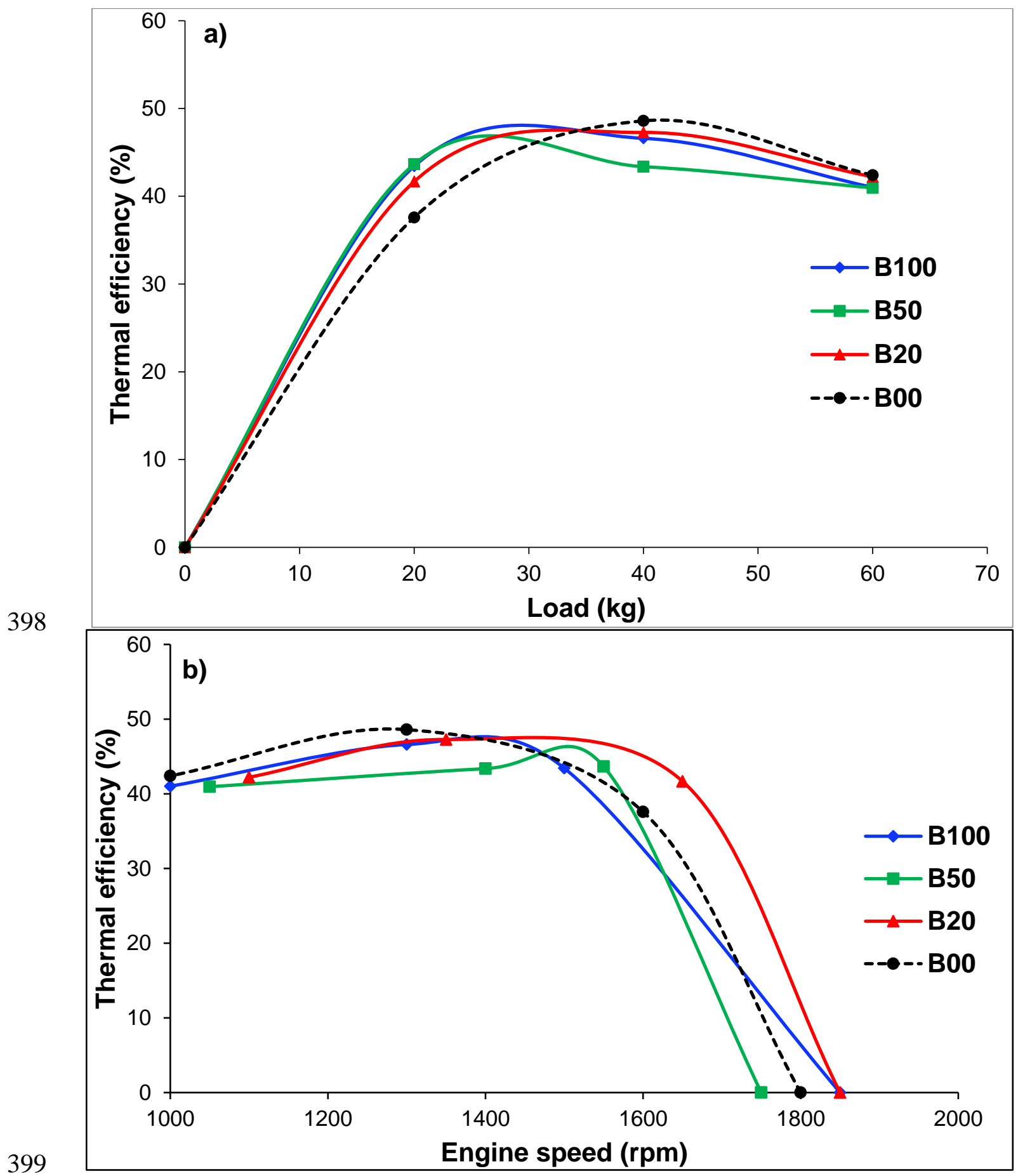

Figure 6: shows a) the thermal efficiency versus load for biodiesel blends and b) the 
407 The impact of changing engine load has a great influence on the brake-specific fuel consumption 408 (BSFC), as seen in Figure 7a. Starting from zero load up to $20 \mathrm{~N}$, a substantial upsurge in fuel 409 consumption was observed due to the fact that at starting load, a very rich fuel mixture needed 410 to overcome the load occurred at the start; after that, the fuel consumption was almost stable. 411 Since the biofuel possessed a lower latent heating value of $39.59 \mathrm{MJ} / \mathrm{kg}$ (Table 1) than that of 412 diesel fuel of $42.25 \mathrm{MJ} / \mathrm{kg}$ (Table 3), pure diesel fuel (B00) is consuming less fuel than other 413 biofuels no matter what the biofuel percentages are, at all engine loads; thus, B100 is the worst 414 case. B00 is the best case of fuel consumption and increasing the Handal oil percentage as 415 biofuel will increase fuel consumption. The blended fuel amount utilised in the engine test 416 should be over that of diesel fuel for realising an identical equivalence ratio. Such a situation 417 results in BSFC augmentation with increasing biofuel percentage in fuel blend, as displayed in 418 Fig. 7 (a, b). BSFC for B20, B50 and B00 was found to decrease with increasing engine load. 419 BSFC was decreased with increased biodiesel amount and increased Handal rate in comparison 420 to those found in varying engine loads. 


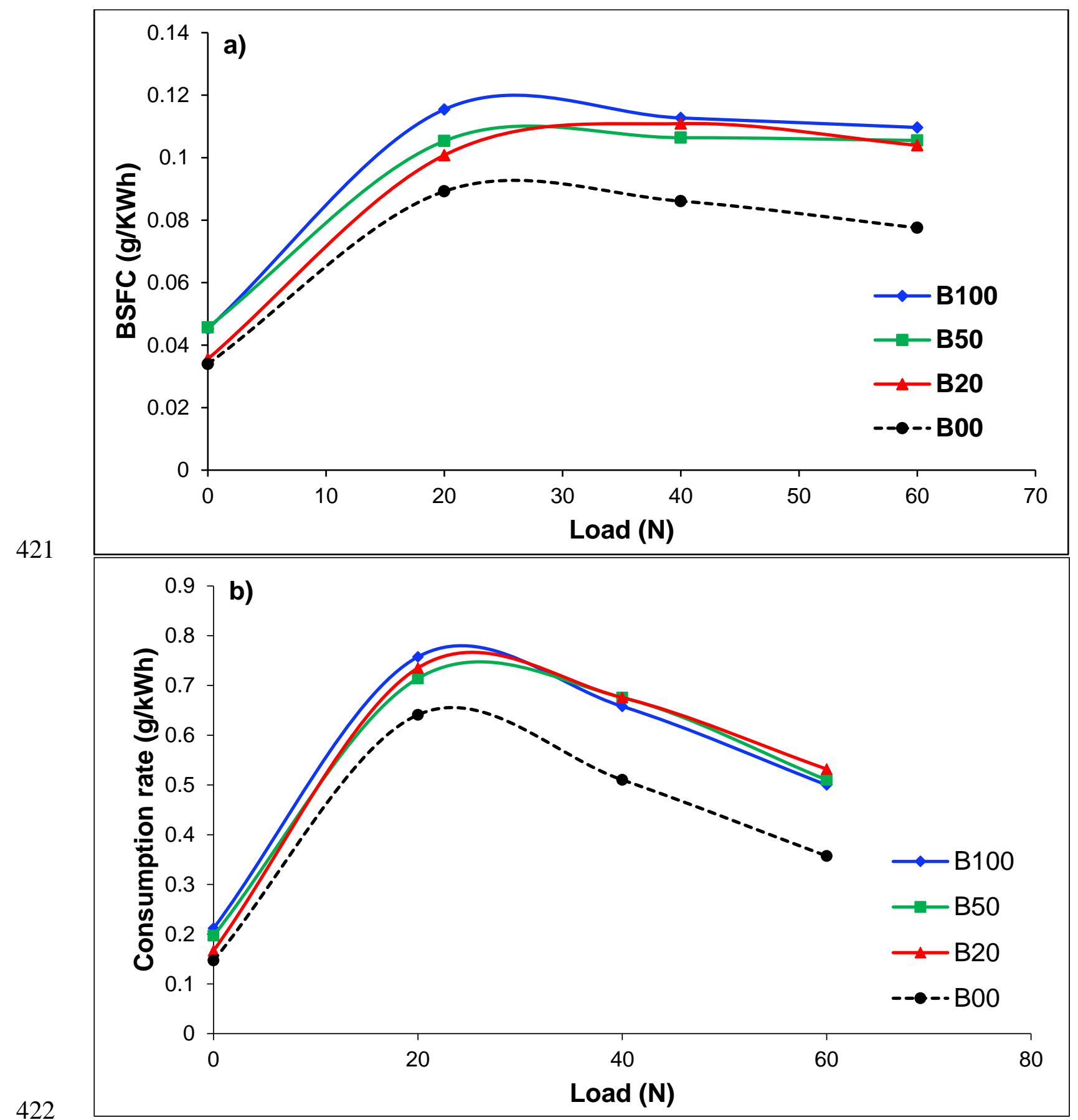

424 Figure 7: shows a) the effect of load on the brake-specific fuel consumption (BSFC) for 425 biodiesel blends and $\mathrm{b})$ the effect of load on the consumption rate ( $\mathrm{g} / \mathrm{kWh}$ ) for biodiesel blends. 426 


\section{Conclusion}

430 Herein, we extracted the Handal seed oil with its conversion into biodiesel along with testing

431 fuel characteristics in the IC engine. The density of Handal seed oil agrees with pre-standard

432 fuels for vegetable oil with compatibility to combustion engines- fuel. The Handal oil kinematic

433 viscosity is larger than that of conventional diesel fuel but shows less value compared to heavy

434 fuel oil. Handal vegetable oil possesses nearly $99 \%$ of the combustion heat of biodiesel. The

$435 \mathrm{HHV}$ of biodiesel $(39.60 \mathrm{MJ} / \mathrm{kg}$ ) is slightly lower than the limit value of $42.2 \mathrm{MJ} / \mathrm{kg}$ for diesel

436 fuels. The blend B20 (20\% Handal oil biodiesel and 80\% diesel fuel), engine performance was

437 significantly higher performance results compared with pure diesel regarding torque, brake

438 power, and efficiency of the engine. Variation of performance parameters for torque engine

439 speed, brake power, and thermal concerning speed engine was relatively similar for blends

440 biodiesel Handal with pure diesel. Thus, Handal can be blended successfully with biodiesel for

441 the IC engine. Brake thermal efficiency improved significantly with an increase in the

442 percentage of biodiesel blending. Hence, in conclusion, the different blends can be

443 recommended for use in diesel engines with no need to modify the engine. The results of engine

444 performance highlighted that the blend B100 (100\% of biodiesel) could be efficiently used in

445 IC engines without affecting the performance of engines. This will help in keeping the

446 environment safe and in the conservation of natural resources for longer use. One significant

447 area surrounds that of engine emissions when using Handal biodiesel, and diesel blends will

448 need further evaluation in future work.

449 Disclaimer:

450 The views and opinions expressed in this paper do not necessarily reflect those of the European

451 Commission or the Special EU Programmes Body (SEUPB).

452

453

454

455

\section{Acknowledgement}

Authors would like to acknowledge the support given by the EPSRC project "Advancing Creative Circular Economies for Plastics via Technological-Social Transitions" (ACCEPT Transitions, EP/S025545/1). AO wish to acknowledge the support of The Bryden Centre project 
(Project ID VA5048). The Bryden Centre project is supported by the European Union's INTERREG VA Programme, managed by the Special EU Programmes Body (SEUPB). The authors wish to acknowledge Charlie Farrell for proofreading the manuscript. The authors would like to express their sincere appreciation to the Deanship of Scientific Research at King Saud University for funding this research project (No. RG1435-078).

\section{References}

464

465

466

467

468

469

470

471

472

473

474

475

476

477

478

479

480

481

482

483

484

485

486

487

488

489

490

491

492

493

494

495

496

497

498

499

500

501

502

503

504

505

[1] A.I. Osman, C. Farrell, A.a.H. Al-Muhtaseb, J. Harrison, D.W. Rooney, The production and application of carbon nanomaterials from high alkali silicate herbaceous biomass, Scientific Reports 10(1) (2020) 2563.

[2] A.I. Osman, Mass spectrometry study of lignocellulosic biomass combustion and pyrolysis with NOx removal, Renewable Energy 146 (2020) 484-496.

[3] M.M. Gui, K.T. Lee, S. Bhatia, Feasibility of edible oil vs. non-edible oil vs. waste edible oil as biodiesel feedstock, Energy 33(11) (2008) 1646-1653.

[4] H. Chen, A.I. Osman, C. Mangwandi, D. Rooney, Upcycling food waste digestate for energy and heavy metal remediation applications, Resources, Conservation \& Recycling: X 3 (2019) 100015.

[5] H. Yamamoto, J. Fujino, K. Yamaji, Evaluation of bioenergy potential with a multi-regional global-land-use-and-energy model, Biomass and Bioenergy 21(3) (2001) 185-203.

[6] S. Fawzy, A.I. Osman, J. Doran, D.W. Rooney, Strategies for mitigation of climate change: a review, Environmental Chemistry Letters 18(6) (2020) 2069-2094.

[7] S.Z. Erhan, S. Asadauskas, Lubricant basestocks from vegetable oils, Industrial Crops and Products 11(2) (2000) 277-282.

[8] K. Kamalakar, T. Satyavani, Y. Mohini, R.B.N. Prasad, M.S.L. Karuna, Synthesis of Thumba, Castor and Sal Fatty Ethanolamide-Based Anionic Surfactants, Journal of Surfactants and Detergents 17(4) (2014) 637-645.

[9] A. Kumar, S. Sharma, Potential non-edible oil resources as biodiesel feedstock: An Indian perspective, Renewable and Sustainable Energy Reviews 15(4) (2011) 1791-1800.

[10] E.N. Ali, C.I. Tay, Characterisation of Biodiesel Produced from Palm Oil via Base Catalyzed Transesterification, Procedia Engineering 53 (2013) 7-12.

[11] G. Kafuku, M.K. Lam, J. Kansedo, K.T. Lee, M. Mbarawa, Croton megalocarpus oil: A feasible non-edible oil source for biodiesel production, Bioresource Technology 101(18) (2010) 7000-7004.

[12] B. Karmakar, B. Ghosh, S. Samanta, G. Halder, Sulfonated catalytic esterification of Madhuca indica oil using waste Delonix regia: L16 Taguchi optimisation and kinetics, Sustainable Energy Technologies and Assessments 37 (2020) 100568.

[13] P.S. Kishore, V. Dhana Raju, M. Kolli, Optimisation of intake parameters for diesel engine fuelled with diesel-tamarind seed methyl ester biodiesel blend by Taguchi method, International Journal of Ambient Energy 41(10) (2020) 1154-1164.

[14] A. Patil, P. Dhanke, V. Kore, N. Kanse, Thumba methyl ester production using prepared novel TiO2 nano-catalyst in ultrasonic cavitation reactor, Materials Today: Proceedings 18 (2019) 4322-4329.

[15] R.B. Sharma, B. Mishra, A. Pal, Production of Bio-Diesel from Non-Edible Thumba ( Citrullus Colocyntis ) Seed Oil Using Mechanical Stirring Methodology and Analysis of Fuel Properties, 2014.

[16] U. Rashid, F. Anwar, B.R. Moser, S. Ashraf, Production of sunflower oil methyl esters by optimised alkali-catalysed methanolysis, Biomass and Bioenergy 32(12) (2008) 1202-1205.

[17] O.D. Hebbal, K.V. Reddy, K. Rajagopal, Performance characteristics of a diesel engine with deccan hemp oil, Fuel 85(14) (2006) 2187-2194. 
[18] E. Dobrzyńska, M. Szewczyńska, M. Pośniak, A. Szczotka, B. Puchałka, J. Woodburn, Exhaust emissions from diesel engines fueled by different blends with the addition of nanomodifiers and hydrotreated vegetable oil HVO, Environmental Pollution 259 (2020) 113772.

[19] P.U. Gaikwad, G. Senthilkumar, S. Bobade, Experimental Investigation and Performance Parameter Analysis of Biodiesel Blend- Methyl Ester on Single Cylinder Diesel Engine, in: P.M. Pawar, B.P. Ronge, R. Balasubramaniam, A.S. Vibhute, S.S. Apte (Eds.) Techno-Societal

[20] A.a.H. Al-Muhtaseb, A.I. Osman, F. Jamil, M. Al-Riyami, L. Al-Haj, A.A. Alothman, H. Htet Kyaw, M. Tay Zar Myint, A. Abu-Jrai, V.K. Ponnusamy, Facile technique towards clean fuel production by upgrading waste cooking oil in the presence of a heterogeneous catalyst, Journal of King Saud University - Science (2020).

[21] S.K. Hoekman, A. Broch, C. Robbins, E. Ceniceros, M. Natarajan, Review of biodiesel composition, properties, and specifications, Renewable and Sustainable Energy Reviews 16(1) (2012) 143-169.

[22] M.A. Fazal, A.S.M.A. Haseeb, H.H. Masjuki, Biodiesel feasibility study: An evaluation of material compatibility; performance; emission and engine durability, Renewable and Sustainable Energy Reviews 15(2) (2011) 1314-1324.

[23] E.R. Sivakumar, R. Senthil, R. Silambarasan, G. Pranesh, S.M. Samuel, Thumba Biodiesel as an Alternative Fuel for CI Engine: Review, 2015.

[24] A.D. Patil, S.S. Baral, P.B. Dhanke, C.S. Madankar, U.S. Patil, V.S. Kore, Parametric studies of methyl esters synthesis from Thumba seed oil using heterogeneous catalyst under conventional stirring and ultrasonic cavitation, Materials Science for Energy Technologies 1(2) (2018) 106-116.

[25] A.I. Osman, N.C. Skillen, P.K.J. Robertson, D.W. Rooney, K. Morgan, Exploring the photocatalytic hydrogen production potential of titania doped with alumina derived from foil waste, International Journal of Hydrogen Energy (2020).

[26] E. Dahdah, J. Estephane, R. Haydar, Y. Youssef, B. El Khoury, C. Gennequin, A. Aboukaïs, E. Abi-Aad, S. Aouad, Biodiesel production from refined sunflower oil over $\mathrm{Ca}-$ $\mathrm{Mg}-\mathrm{Al}$ catalysts: Effect of the composition and the thermal treatment, Renewable Energy 146 (2020) 1242-1248.

[27] N. Vardast, M. Haghighi, S. Dehghani, Sono-dispersion of calcium over Al-MCM-41used as a nanocatalyst for biodiesel production from sunflower oil: Influence of ultrasound irradiation and calcium content on catalytic properties and performance, Renewable Energy 132 (2019) 979-988.

[28] M.S. Gad, S. Jayaraj, A comparative study on the effect of nano-additives on the performance and emissions of a diesel engine run on Jatropha biodiesel, Fuel 267 (2020) 117168.

[29] S.O. Giwa, T.O. Akanbi, A Review on Food Uses and the Prospect of Egusi Melon for Biodiesel Production, BioEnergy Research (2020).

[30] M.R. Abukhadra, A.S. Mohamed, A.M. El-Sherbeeny, A.T.A. Soliman, A.E.E. Abd Elgawad, Sonication induced transesterification of castor oil into biodiesel in the presence of $\mathrm{MgO} / \mathrm{CaO}$ nanorods as a novel basic catalyst: Characterisation and optimisation, Chemical Engineering and Processing - Process Intensification 154 (2020) 108024.

[31] Z.-h. Ni, F.-s. Li, H. Wang, S. Wang, S.-y. Gao, L. Zhou, Antioxidative performance and oil-soluble properties of conventional antioxidants in rubber seed oil biodiesel, Renewable Energy 145 (2020) 93-98.

[32] J. Gupta, M. Agarwal, A.K. Dalai, Intensified transesterification of mixture of edible and non-edible oils in reverse flow helical coil reactor for biodiesel production, Renewable Energy 134 (2019) 509-525. 
[33] D. Kumar, T. Das, B.S. Giri, B. Verma, Preparation and characterisation of novel hybrid bio-support material immobilised from Pseudomonas cepacia lipase and its application to enhance biodiesel production, Renewable Energy 147 (2020) 11-24. [34] S.O. Giwa, T.O. Akanbi, Mechanisation of melon processing and novel extraction technologies: A short review, Scientific African 9 (2020) e00478. [35] S. Qayoom, S. Kanchan, Performance and Emission Characteristics of Thumba Oil Based Biodiesel on Diesel Engine: A Comprehensive Review, Asian Journal of Water, Environment and Pollution 15 (2018) 93-101.

563 Effects of light, temperature, salinity, and maternal habitat on seed germination of Aeluropus lagopoides (Poaceae): an economically important halophyte of arid Arabian deserts, Botany 98(2) (2019) 117-125.

\section{[37]}

A. D.P.M.S.N.B. AKASH S., Biodiesel from Thumba Oil Characterization and Performance Testing In Internal Combustion Engine. , International Research Journal of Engineering and Technology (IRJET) 3(12) (2016) 511-517. .

[38] S.B. Chavan, R.R. Kumbhar, Y.C. Sharma, Transesterification of Citrullus colocynthis (Thumba) oil: optimisation for biodiesel production, Advances in Applied Science Research 5(3) (2014) 10-20.

[39] H.C. Ong, A.S. Silitonga, H.H. Masjuki, T.M.I. Mahlia, W.T. Chong, M.H. Boosroh, Production and comparative fuel properties of biodiesel from non-edible oils: Jatropha curcas, Sterculia foetida and Ceiba pentandra, Energy Conversion and Management 73 (2013) 245255.

[40] X. Cao, M.N. Islam, Z. Duan, X. Pan, W. Xu, X. Wei, S. Zhong, Chlorogenic acid osmosis of snakehead fish: a novel approach to maintain quality and suppress deterioration during storage, International Journal of Food Properties 23(1) (2020) 387-399.

[41] M. Chai, Q. Tu, M. Lu, Y.J. Yang, Esterification pretreatment of free fatty acid in biodiesel production, from laboratory to industry, Fuel Processing Technology 125 (2014) 106-113.

[42] J.-H. Ng, H.K. Ng, S. Gan, Advances in biodiesel fuel for application in compression ignition engines, Clean Technologies and Environmental Policy 12(5) (2010) 459-493.

[43] L.N. de Melo, L.A. Santana, P.F. da Rocha, S.M.P. Meneghetti, M.R. Meneghetti, J.H. Bortoluzzi, Studies on Inter- and Transesterification: Different Oils with the Same Fatty Acid Composition and Their Reaction Behaviors, Energy \& Fuels 34(5) (2020) 5948-5957.

[44] W. Jun, W. Weiwei, W. Xudong, W. Min, W. Fuan, An effective GC method for the determination of the fatty acid composition in silkworm pupae oil using a two-step methylation process, Journal of the Serbian Chemical Society 80 (2015) 9-20.

[45] D Balajee, G Sankaranarayanan, P Harish, a.N. Jeevarathinam, Performance and Combustion Characteristics of CI Engine with Variable Compression Ratio Fuelled with Pongamia and Jatropha and its Blends with Diesel, Int. J. Mech. Eng. \& Rob. Res. 2(3) (2013) 74-85. .

[46] E. Sikakumar, R. SENTHIL, R. SILAMBARASAN, G. PRANESH, S. \& SAMUEL, An Experimental Investigation On Performance, Emission And Combustion Characterstics Of Thumba Oilmethyl Ester Blends In A Di Diesel Engine., Journal Of Chemical And Pharmaceutical Sciences 7 (2015) 301-304. .

[47] G. Karmakar, P. Ghosh, B.K. Sharma, Chemically Modifying Vegetable Oils to Prepare Green Lubricants, Lubricants 5(4) (2017) 44.

[48] F. Jiménez Espadafor, M. Torres García, J. Becerra Villanueva, J. Moreno Gutiérrez, The viability of pure vegetable oil as an alternative fuel for large ships, Transportation Research Part D: Transport and Environment 14(7) (2009) 461-469. 
606 Production Of Thumba Methyl Ester. , International Journal Of Innovative Research In Science, 607 Engineering And Technology (IJIRSET), 5 (2016) 311-316. .

608 [50] A. Karnwal, N. Kumar, M.M. Hasan, R. Chaudhary, A. Noor Siddiquee, Z. A. Khan, 609 Production of Biodiesel from Thumba Oil: Optimisation of Process Parameters, Iranian 610 (Iranica) Journal of Energy \& Environment 1(4) (2010).

611 [51] G. Knothe, Analysing biodiesel: standards and other methods, Journal of the American Oil 612 Chemists' Society 83(10) (2006) 823-833.

613 [52] S.S. Sidibé, J. Blin, G. Vaitilingom, Y. Azoumah, Use of crude filtered vegetable oil as a 614 fuel in diesel engines state of the art: Literature review, Renewable and Sustainable Energy 615 Reviews 14(9) (2010) 2748-2759.

616 [53] A. Demirbaş, Fuel properties and calculation of higher heating values of vegetable oils, 617 Fuel 77(9) (1998) 1117-1120.

618 [54] A. Hafidi, D. Pioch, H. Ajana, Membrane-based simultaneous degumming and 619 deacidification of vegetable oils, Innovative Food Science \& Emerging Technologies 6(2) 620 (2005) 203-212.

621 [55] B. Likozar, J. Levec, Transesterification of canola, palm, peanut, soybean and sunflower 622 oil with methanol, ethanol, isopropanol, butanol and tert-butanol to biodiesel: Modelling of 623 chemical equilibrium, reaction kinetics and mass transfer based on fatty acid composition, 624 Applied Energy 123 (2014) 108-120.

625 [56] J.J. Thomas, C.V. Manojkumar, V.R. Sabu, G. Nagarajan, Development and validation of 626 a reduced chemical kinetic model for used vegetable oil biodiesel/1-Hexanol blend for engine 627 application, Fuel 273 (2020) 117780.

628 [57] J. Thangaraja, V. Srinivasan, Techno-economic assessment of coconut biodiesel as a 629 potential alternative fuel for compression ignition engines, Environmental Science and 630 Pollution Research 26(9) (2019) 8650-8664.

631 [58] E.D. Dutra, T.A. de Lima, J.L. de Oliveira Souza, J.G.V. Silva, K.A. da Silva Aquino, F. 632 da Silva Aquino, C.S. Ramos, R.S.C. Menezes, Characterization of fat and biodiesel from 633 mango seeds using 1H NMR spectroscopy, Biomass Conversion and Biorefinery 8(1) (2018) 634 135-141.

635 [59] A. Srivastava, R. Prasad, Triglycerides-based diesel fuels, Renewable and Sustainable 636 Energy Reviews 4(2) (2000) 111-133.

637 [60] P.N. Giannelos, F. Zannikos, S. Stournas, E. Lois, G. Anastopoulos, Tobacco seed oil as 638 an alternative diesel fuel: physical and chemical properties, Industrial Crops and Products 16(1) 639 (2002) 1-9.

640 [61] B.R. Moser, S.F. Vaughn, Evaluation of alkyl esters from Camelina sativa oil as biodiesel 641 and as blend components in ultra low-sulfur diesel fuel, Bioresource Technology 101(2) (2010) 642 646-653.

643 [62] A. Bartošová, T. Štefko, Gas Chromatographic Determination of Fatty Acids in Oils with 644 Regard to the Assessment of Fire Hazard, Research Papers Faculty of Materials Science and 645 Technology Slovak University of Technology 25(40) (2017) 73.

646 [63] A. DemİRbaŞ, Chemical and Fuel Properties of Seventeen Vegetable Oils, Energy Sources 647 25(7) (2003) 721-728. 